\title{
Practice of Original Movie Clips in English Teaching
}

\author{
Guopei Pan \\ Nanchang Institute of Science and Technology \\ Nanchang, Jiangxi, China
}

\begin{abstract}
With the rapid development of multi-media technology, English teaching is aided by original movies. And it has widely became a sort of teaching mode, which is extensively used by teachers. With widespread content, strong narration and vivid speech, original movies in English come from life. If they applied to English teaching, it may break through limitations of teaching materials. And it greatly improves students' enthusiasm in learning. So classroom teaching may be greatly enriched. According to cutting movie clips, editing and processing some pictures and voices, teachers may make some English teaching courseware apply to class teaching and scientifically arrange the entire class to greatly enhance teaching effects in the practice of multi-media classroom teaching.
\end{abstract}

Keywords-Original Movie Clip; English Teaching Courseware; Choice of Materials

\section{INTRODUCTION}

With the more popularity of multi-media teaching and the more rapidity of Internet development, the English teaching mode by simply 'teachers' instruction and students' practice" in the past hasn't rather met the demand of present English teaching. How to get the greatest class teaching effect is what teachers must consider. Although it is possible that using the existing multi-media English teaching courseware can create the best visual and aural effect for students, you cannot get all-embracing teaching courseware in the market. Sometimes teachers probably difficultly find some teaching resources relevant to teaching contents, so it is necessary that teachers make some courseware closely connected with teaching contents by their own so as to make students absorb knowledge in classrooms.

\section{APPROPRIATE CHOICE OF TEACHING MATERIAL IS THE REQUISITE OF CONDUCTING EFFICIENT CLASSROOM \\ TEACHING}

Original movies are very popular with students owing to their having plots, vivid pictures, and idiomatic speech. Many teachers also pay much attention to choosing right original movies to enrich classroom teaching.

However, in the practice of teaching through using movies, the author found that it was feasible to play the entire movie to amuse students. The effect of the whole classroom got by doing so was not rather ideal. Therefore, the author thinks that we should select some movies relevant to our teaching contents, intercept a few of their own 5-10 minutes' clips, necessarily edit and process them, and then put them into use in classrooms. The effect attained by this method is better.

In the course of choosing movie materials, we should accurately grasp movie clips' ideological level, interest, and appreciation. Their language source should be American English or British English; their subtitles and captions should be provided with bilingual Chinese and English. It is better that subtitles and captions can mutually switch. Certainly, in observing and choosing subtitles, whether or not their target language' translation being accurate, coherent should be attached much importance to. Otherwise, these clips will probably mislead students.

\section{CAREFul CREATION OF TEAChING Courseware Is POWERFUL GUARANTEE OF CONDUCTING EFFICIENT TEACHING}

Courseware is applied teaching software created by teachers or programmer through certain computer language or courseware writing system in accordance with teaching requirements concerned. The aim of designing and making courseware is to show teaching information by sufficiently using many multi-media means such as characters, sound, images, and video clips and so on. Multi-media teaching is an advanced teaching means and is characteristic of integration of graphs, sound, action, and characters. So, utilizing multi-media courseware to conduct teaching may stimulate students' many organs such as eyes, ears, mouth, and brain from various aspects and greatly activate their thinking to smoothly reach teaching aims.

\section{A. Original Movie Pictures' Introduction into Courseware}

For vocational college students, now that learning public English is a difficult thing, to what degree they learn vocational English is imaginable. For teachers, to successfully teach vocational English has to be a challenge since teaching software concerned with vocational English is too hard to be found in the market.

Through a few years' teaching practice, the author found that the teaching effects would be better if elaborately selected original movie clips could be integrated into multimedia teaching courseware to conduct classroom teaching. When teaching the unit of Apparel English "design details", the author ever intercepted ten minutes' clip picture from 01:17:00 to 01:27:00 of "The Devil Wears Prada", processed and edited the clip to get some necessary pictures as the author had wished, and integrated it into some courseware. In the clip, there was a fashion show, that author ever tried to clip some pictures of model fashion shows, edited into some 
necessary written information so that students could easier absorb the contents what they should grasp in the class. For instance, the first model's fashion show picture may be illustrated with the written English like this: "the dress is made of chiffon, and decorated with lace and light color patterns. Halter neckline is one of its design styles." The sixth model's show picture may be illustrated with the written English like this: "Oblique neckline and many pleats are adapted in the dress's design."

Through teaching by this means, students generally reflected that what teachers had taught in the classroom was easier to absorb, and professional terms was also quicker to suck into their minds.

\section{B. Original Movie Sound' Introduction into Courseware}

The aim of conducting classroom teaching by using original movie clip is not only to deepen students' comprehension of knowledge what they have learned, but also to improve students' listening ability. The speed of original movie is generally rather quick, sometimes gets beyond their reach. In order to solve this problem, the author tried to make and convert the clip's vocal information from 23 minutes to 28 minutes of the movie into a piece of courseware, which can be played at 3 speech speed (slower; a little slow; normally). For example, Miranda Priestly comments about sky-blue:

"And you're also blithely unaware of the fact that in 2002, Oscar de la Renta did a collection of cerulean gown. And then I think it was Yves Saint Laurant, wasn't it? Who showed cerulean military jackets? Ana then cerulean quickly showed up in the collection of eight different designers."

In this way, after repeatedly trained, students can get complete listening grasp of the clip. Practice proved the means was feasible.

\section{SCIENTIFICALly GRASPING TEACHING PROCESS IS THE KEY TO SUCCESSFULLY CONDUCTING EFFICIENT CLASSROOM TEACHING}

So as to conduct efficient English teaching with the aid of original movie clips, teachers have to match with some necessary teaching courseware (including static picture courseware and vocal courseware). It will be better, if motioned pictures can be made. Its making technology is rather complicated. Generally speaking, 10 minutes' clip needs about 45----60 minutes' teaching practice to attain teaching objective. The entire teaching process can be divided into the following 3 stages.

The first stage: appreciation. While organizing students to appreciate movie pictures, teachers must adeptly design exercises, make students watch the clip with questions, the aim being clear. For instance, as for the clip with fashion shows above described, the following questions can be designed.

- A. Which season is the dress in the show suitable for?

- B. For whom is Miranda in tears?
The second stage: commentary. After watching a clip, students can not have too much grasp of what they have watched, there being a certain point where they have difficultly comprehend. When playing for the second time, as soon as there are elusive words or sentences showed in the clip, teachers need to pause to explain difficult points concerned in details. Teachers had better explain while playing. During commentary teachers should switch into some courseware made on the basis of clips to show students. Only doing like that, students' every organ or nerve can be activated; the best teaching effect can be reached. For instance, there is a line in the clip: "You like the collection? Absolutely, I think it's the best in years." The word of line "collection", its definition in subtitles is "show". If you look up this word in dictionaries, its explanation isn't linked to show. Therefore, teachers' illustration appears to be especially important. In fact, the word "collection" is a common fashion English term which means "apparel series". After students understand its meaning, teachers had better make one or two sentences with the word and play courseware matching pictures relevant to sentences concerned with the term. For instance:

- A. "the perfect combination of modernism and classicism in fully shown the collection."

- B. "The collection was created by a famous designer."

The third stage: improvement and consolidation. After teachers explain keywords concerned, students can have an overall and clear of the whole information they should get from the clip and situational dialogue. At this time, teachers play the clip once again. When finished, students ask teachers questions. Teachers can make collective response to the questions students have asked. Confirming that students have a basic grasp of the information from the clip, teachers can play the clip for the fourth time. This time's clip played should be without subtitles, so students have to capture vocal information with their ears without interference of subtitles. After playing, teachers may properly give students free space; offer them a setting for role play. This process can completely develop students' subjective initiative and imagination, cultivate their language sense. With efficient aid of body language and facial expression, talking in Standard English, they can perfectly mimic roles played in the clip, which can be personally on the scene. This can play an important role in cultivating students' interest in learning English.

In the final phase of movie clip teaching, it is essential that teachers organize some activities and assign some work. They can divide students into groups (each group: 5 people) to discuss 2 topics. For example:

- How do you comment on the collection in the movie clip?

- What do you think is the fashion? Teachers can make students dictate some classic lines, such as "the point is we really need to figure out where to place Donatella" or demand students to write down a 
composition and comment on heroine's wear or decorations.

\section{CONCLUSION}

Utilizing authentic audiovisual materials such as original movie clips to arrange teaching activity is a new pattern "containing education in amusement," which is worth trying. The pattern may not only activate students' initiative of learning English, but also get rid of monotonous, dull study pattern. According to doing this, teachers will open up a vivid and interesting path to success for students.

To do this is certainly a challenge for teachers. In order to better arrange teaching activities, teachers need spend a lot of time in watching original edition movie again and again. Sometimes, consulting the materials and turning to foreign teachers for help is necessary. Furthermore, teaching like this can also stimulate and enhance their professional level. As long as teachers elaborately design and strictly organize teaching activities in combination with students' existing situation and in accordance with teaching program. They can not only improve English learners' language skill in every respect, but also enhance students' cross-cultural communication awareness and ability. Combining with the English situation, the aid of modern educational technology, English teachers take advantages of original edition movie to make classroom filled with interest and efficiency. And it is in accordance with their aptitude.

\section{REFERENCES}

[1] Lu Aibing Original Edition and English Teaching[J]. Creative Guide of Chinese Science Education, 2010(16).

[2] Xie Jiali The Application of Original Edition movie in the Teaching of High Vocational Listening and Speaking[J]. Research into New Course, 2009(03)

[3] Wang Xianghua Acceptability of Foreign Movie and Movie Translation[J]. Movie Literature, 2009 (10).

[4] Zhang Rui Corresponding Tactics in Culture of Movie Translation[J]. Movie Literature, 2009 (10).

[5] Zhang Lingna Role Analysis of Teachers of Original Edition movie Applied to English Teaching[J]. Off-Campus Education of China, 2010(06). 